\title{
Assessment of Heavy Metal Pollution through Index Analysis for Yamuna Water in Agra Region, India
}

\author{
Rama Pal $^{1 *}$, R.K. Dubey ${ }^{2}$, S.K. Dubey ${ }^{3}$ and A.K. Singh ${ }^{3}$ \\ ${ }^{1}$ CBSH, G.B. Pant University of Agriculture and Technology, Pantnagar, India \\ ${ }^{2}$ Indian Agricultural Research Institute, New Delhi, India \\ ${ }^{3}$ ICAR-Indian Institute of Soil and Water Conservation, Research Centre, Chhalesar, \\ Agra 282006 (Uttar Pradesh), India \\ *Corresponding author
}

\begin{abstract}
A B S T R A C T
Keywords

Heavy metal pollution, Analysis, Yamuna water.

Article Info

Accepted:

12 October 2017

Available Online:

10 December 2017

The present study was conducted on heavy metal pollution of Yamuna river water in Agra region at sites viz., A1, A2, A3, A4 and A5 for summer and post-rainy seasons. Mean concentration of heavy metals followed the order $\mathrm{Zn}>\mathrm{Fe}>\mathrm{Cu}>\mathrm{Ni}$ $\geq \mathrm{Mn}>\mathrm{Cr}>\mathrm{Pb}>\mathrm{Cd}$ in summer and $\mathrm{Zn}>\mathrm{Fe}>\mathrm{Mn}>\mathrm{Cu}>\mathrm{Ni}>\mathrm{Cr}>\mathrm{Pb}>\mathrm{Cd}$ in postrainy seasons. $\mathrm{Zn}$ and $\mathrm{Cu}$ were within permissible limit for drinking water quality at all sites in both seasons. Fe, $\mathrm{Zn}, \mathrm{Cr}$ and $\mathrm{Mn}$ increased during post-rainy season against their covalent index. Mean heavy metal pollution index (HPI) for each sampling site reflected highest pollution at A4 site. Mean HPI for Yamuna water in summer (261) decreased conspicuously in post-rainy season (92.5). Metal quality index (MQI) values were highest at A4 site i.e., 23.15 in summer and 22.0 in post-rainy seasons. Pearson's analysis showed significant positive correlation among all heavy metals.
\end{abstract}

\section{Introduction}

Rapid urbanization, industrialization and population growth in burgeoning cities has led to increased flux of heavy metals laden wastewater into India's rivers traversing through these cities (Paul, 2017). Heavy metals can enter river systems mainly from point and non-point sources i.e., effluents of industrial activities, domestic wastewater, runoff from agricultural fields and urban areas which supply huge quantities of inorganic ions and heavy metals (Bhardwaj et al., 2017; Pandey and Singh, 2017). Heavy metals such as cobalt $(\mathrm{Co})$, copper $(\mathrm{Cu})$, chromium $(\mathrm{Cr})$, iron $(\mathrm{Fe})$, magnesium $(\mathrm{Mg})$, manganese $(\mathrm{Mn})$, molybdenum (Mo), nickel (Ni), selenium (Se) and zinc $(\mathrm{Zn})$ are required to maintain various biochemical and physiological functions in living organisms when in very low concentrations, however, they become toxic when exceed certain threshold concentrations (Jaishankar et al., 2014). Whereas nonessential heavy metals such as aluminium (Al), antinomy (Sb), arsenic (As), barium (Ba), beryllium $(\mathrm{Be})$, bismuth $(\mathrm{Bi})$, cadmium (Cd), gallium (Ga), germanium (Ge), gold $(\mathrm{Au})$, indium $(\mathrm{In})$, lead $(\mathrm{Pb})$, lithium $(\mathrm{Li})$, 
mercury $(\mathrm{Hg})$, platinum $(\mathrm{Pt})$, silver $(\mathrm{Ag})$, strontium ( $\mathrm{Sr})$, tellurium (Te), thallium $(\mathrm{Tl})$, tin (Sn), titanium (Ti), vanadium (V) and uranium (U) are toxic even at very low concentration (Paul, 2012). Monitoring of heavy metal contamination in rivers is important because heavy metals pose threat to aquatic life, human health and to the environment due to biomagnifications and their toxicity (Ahmed et al., 2015; Ali et al., 2016). The interpretation of spatial and seasonal concentration of heavy metals through HPI can be useful in assessment of degree of pollution load and water quality trend of a river (Reza and Singh, 2010; Prasanna et al., 2012). HPI of a river can be a useful tool for regulatory agencies to make necessary policies and decisions regarding pollution abatement and resource management. The metal quality indices have been computed to assess the suitability level of water resources for drinking with respect to metals (Ojekunle et al., 2016).Pearson's correlation analysis can be an effective tool for identification of pollution sources, to apportion natural versus anthropogenic or mixed contributions (Yalcin et al., 2010; Manoj et al., 2012).

Yamuna is the life artery of Agra district in Uttar Pradesh, representing the main freshwater resource required for meeting domestic, industrial and irrigation water demands. The catchment area of Yamuna in Agra is highly urbanized and is networked by several drains. Fort drain is the largest drain that discharges a heavy load of pollutants into the river. Water quality evaluation of Yamuna with respect to heavy metals is very important to realize the feasibility of its use for drinking. The river Yamuna has been monitored several times for the presence of heavy metals in various cities (Kaurand Mehra, 2012; Malik et al., 2014). However, in present study first time an attempt has been made to evaluate the current heavy metal $(\mathrm{Fe}, \mathrm{Pb}, \mathrm{Cd}, \mathrm{Cr}, \mathrm{Cu}, \mathrm{Ni}$,
Mn) based water quality of Yamuna's stretch in Agra using indices i.e., heavy metal pollution index (HPI), metal quality index (MQI) (Abdel-Satar et al., 2017) and Pearson's correlation analysis.

\section{Materials and Methods}

Water samples were collected from five sites i.e., A1, A2, A3, A4 and A5 along the Yamuna river stretch in Agra district (Fig. 1) during summer (May 2016) and post-rainy seasons (October 2016). Sites A2, A3 and A4 were lying inside the municipality zone of Agra, hence, these sites carried wastes of various municipality drains discharging into Yamuna. Whereas, A1 and A5 sites were lying outside the municipality zone and $5 \mathrm{Km}$ upstream and downstream of the first and last municipality drains, respectively. The samples collected from each site consisted of 3 composite samples taken from 1 foot below the water surface using acid washed $500 \mathrm{ml}$ polyethylene bottles to avoid unpredictable changes in characteristics. Water samples collected were placed at $4^{\circ} \mathrm{C}$ in an ice-jacket and transported to the laboratory immediately for further analysis. The collected samples were acidified with concentrated nitric acid to a $\mathrm{pH}$ below 2.0 to minimize precipitation and adsorption on bottles walls as required by the standard procedure. The concentrations of heavy metals were determined using an atomic absorption spectrometry (PerkinElmer, 3300/96, MHS-10) after acid-digestion procedure for heavy metals analysis as per APHA (2012). All analyses were carried out in triplicate, and the results were expressed as the mean.

The HPI shows overall quality of water with respect to content of heavy metals. The critical HPI value is 100 . The weighted arithmetic average of the concentrations was used to calculate HPI values using the Eq. 1 given by Mohan et al., (1996): 
$H P I=\frac{\sum_{i=1}^{n} W i Q i}{\sum_{i=1}^{n} W i}(1)$

Where $\mathrm{Wi}$ is the unit weightage defined as reciprocal value of $\mathrm{Si}$ where $\mathrm{Si}$ is the maximum permissible limit for drinking water given by BIS (2012), and $\mathrm{n}$ is the number of parameters considered. Qi isthe sub-index of the $\mathrm{i}^{\text {th }}$ parameter, and calculated by Eq. 2

$Q i=\sum_{i=1}^{n} \frac{M i}{S i} \times 100(2)$

Where Mi is the monitored value of heavy metal, $\mathrm{Si}$ is the standard value of the $i^{\text {th }}$ parameter, in ppm $(\mu \mathrm{g} / \mathrm{L})$.

The higher the concentration of a metal compared to its respective maximum permissible limit $(\mathrm{Si})$, the worse the quality of the water. MQI value $>1$ is a threshold of warning (Bakan et al., 2010). According to (Tamasi and Cini, 2004), the MQI is calculated by Eq. 3

$M Q I=\sum_{i=1}^{n} M i / S i(3)$

The data were statistically analyzed using the SPSS 20.0statistical software package to calculate average, standard deviation, Pearson's correlation coefficient and level of significance. Level of significance was calculated at $\mathrm{p}<0.05$.

\section{Results and Discussion}

The concentrations of eight heavy metals analysed for summer and post-rainy seasons and some basic statistics are shown in Table 1. The mean concentration of heavy metals in Yamuna water followed the order $\mathrm{Zn} \mathrm{(1660}$ $\left.\mu \mathrm{gl}^{-1}\right)>\mathrm{Fe}\left(420 \mu \mathrm{gl}^{-1}\right)>\mathrm{Cu}\left(256 \mu \mathrm{gl}^{-1}\right)>\mathrm{Ni}$ $\left(166 \mu \mathrm{gl}^{-1}\right) \geq \mathrm{Mn}\left(162 \mu \mathrm{gl}^{-1}\right)>\mathrm{Cr}\left(40 \mu \mathrm{gl}^{-1}\right)>\mathrm{Pb}$ $\left(34 \mu \mathrm{gl}^{-1}\right)>\mathrm{Cd}\left(5 \mu \mathrm{gl}^{-1}\right)$ in summer and $\mathrm{Zn}$ $\left(2480 \mu \mathrm{gl}^{-1}\right)>\mathrm{Fe}\left(608.5 \mu \mathrm{gl}^{-1}\right)>\mathrm{Mn}\left(417 \mu \mathrm{gl}^{-}\right.$ $\left.{ }^{1}\right)>\mathrm{Cu}\left(185.8 \mu \mathrm{gl}^{-1}\right)>\mathrm{Ni}\left(86.6 \mu \mathrm{gl}^{-1}\right)>\mathrm{Cr}(71$ $\left.\mu \mathrm{gl}^{-1}\right)>\mathrm{Pb}\left(12.7 \mu \mathrm{gl}^{-1}\right)>\mathrm{Cd}(0.8)$ in post-rainy season. The concentration of all heavy metals were highest at A4 site because it is positioned downstream of the biggest drain of Agra i.e., Fort Drain which carried waste discharged from most of the chemical and fertilizer industries and residential areas of the city. Except $\mathrm{Zn}-\mathrm{Cu}-\mathrm{Mn}$ in summer and $\mathrm{Zn}-\mathrm{Cu}$ in post-rainy season, all other heavy metals inside the municipality zone were above maximum permissible limits for drinking water quality given by BIS (2012). The concentrations of different heavy metals increased continuously from A1 to A4 sites but decreased conspicuously at A5 during both seasons which may be due to the fact that A5 site being located $5 \mathrm{Km}$ downstream of last municipality drain of the city, the distance provided sufficient time for heavy metals to settle down from dissolved phase to the bed sediments of river. During transportation of heavy metals in the river, it may undergo dissolution, precipitation and sorption (Abdel-Ghani and Elchaghaby, 2007).

In summers, Fe concentration was found 1.5 to 2.3 times higher than maximum permissible limit for drinking water quality from A2 to A4 sites, whereas within limits at A1 and A5 sites. However, in post-rainy season mean $\mathrm{Fe}$ concentration increased1.4 times and reported 1.1 to 3.5 times higher than maximum permissible limit at all sites except at A1. High Fe levels can be accounted to municipal and metal industry waste waters. $\mathrm{Pb}$ was found 2 to 6 times higher than maximum permissible limit for drinking water quality at all sites in summers, whereas 2 to 3 times higher between A2 to A4 sites in postrainy season. Source of $\mathrm{Pb}$ pollution may be lead acid batteries manufacturing industries. Cd was 1.3 to 27 times higher than maximum permissible limit for drinking water quality from A2 to A5 sites in summers and 1.3 times higher at only A4 site in post-rainy season. Its source was wastewater coming from electroplating and painting industries located 
in the city. The concentrations of $\mathrm{Zn}$ and $\mathrm{Cu}$ were found within permissible limit for drinking water quality at all sites in both seasons which indicated that they were not significant source of pollution in Yamuna. In summer, $\mathrm{Cr}$ concentration was reported 1.6 times higher than maximum permissible limit for drinking water quality at A4 site, whereas within the limit at other sites. However, its mean concentration increased 1.8 times in post-rainy season and found 1.7 and 3.2 times higher than maximum permissible limit at $\mathrm{A} 3$ and A4 sites, respectively.

The high levels of $\mathrm{Cr}$ may be due to prominence of leather tanning industries in the city. $\mathrm{Ni}$ was reported 6 to 11.5 times higher than maximum permissible limit for drinking water quality at all sites in summer, whereas its mean concentration decreased significantly in post-rainy season and was reported 3.4 to 7.8 times higher than maximum permissible limit between A2 to A5 sites. The presence of stainless steel and refining industries in city contributed to high level of $\mathrm{Ni}$ in river. $\mathrm{Mn}$ concentrations were found under the maximum permissible limit for drinking water quality at all sites in summer, whereas its mean concentration increased by 2.6 times in post-rainy season and found 1.12 to 2.6 times higher than maximum permissible limit for drinking water quality between $\mathrm{A} 3$ to $\mathrm{A} 5$ sites.

The concentration of $\mathrm{Pb}, \mathrm{Cd}, \mathrm{Cu}$ and $\mathrm{Ni}$ decreased in post-rainy season due to dilution effect, whereas concentration of $\mathrm{Fe}, \mathrm{Zn}, \mathrm{Cr}$ and $\mathrm{Mn}$ increased which can be accounted to desorption of these metals from sediments due to dilution. Heavy metals enter into the rivers as inorganic complexes or hydrated ions, which are easily adsorbed on surface of sediment particles and constitute the labile fraction (Vukovic et al., 2014). The increase in mean concentration of $\mathrm{Fe}, \mathrm{Zn}, \mathrm{Cr}$ and $\mathrm{Mn}$ in post-rainy season with respect to summer followed the order as $\mathrm{Mn}>\mathrm{Cr}>\mathrm{Zn}>\mathrm{Fe}$ which was inversely proportional to their covalent index $\mathrm{Fe}>\mathrm{Zn}>\mathrm{Cr}>\mathrm{Mn}$. Higher the covalent index of a heavy metal stronger will be its adsorption (Pal and Rai, 2009) and hence lower will be its desorption due to dilution. Desorption of other heavy metals i.e., $\mathrm{Pb}, \mathrm{Cd}$, $\mathrm{Cu}$ and $\mathrm{Ni}$ also would had occurred but dilution was dominant factor, hence net result was decrease in concentration.

The mean concentrations of eight heavy metals $(\mathrm{Pb}, \mathrm{Cd}, \mathrm{Fe}, \mathrm{Zn}, \mathrm{Mn}, \mathrm{Cu}, \mathrm{As}$ and $\mathrm{Hg}$ ) were taken for determination of the HPI values. Table 2 provides details of calculating HPI, Wi and Qi values for both seasons. The critical value of the heavy metals pollution index is 100 (Milivojević, 2016). The mean HPI for Yamuna in summer (261) decreased significantly in post-rainy season (92.5). Hence, overall HPI of Yamuna was 176.75 which was above critical limit.

The high HPI values were mainly due to industrial and domestic wastewater discharge into river. HPI of different sampling sites were compared to assess pollution load and assess the water quality for the selected sites (Table 3). HPI values were above the critical index limit at all sites in summer, whereas only at A4 site in post-rainy season.

Also, from the values of mean HPI for each sampling site could be concluded that the pollution load at sampling site A4 was most significant (HPI 412 in summer and 238.5 in post-rainy season).

Another index, metal quality index, was used to estimate the metal pollution of Yamuna water for drinking use by computing all measured metals (Table 4). All sites along the studied stretch were seriously threatened with metal pollution for drinking (MQI > 1), MQI reached to 23.15 and 22.0 at site A4 in summer and post-rainy seasons, respectively. 
Table.1 Heavy metal concentrations in river water at different sampling sites and statistical values for mean concentration of various heavy metals

\begin{tabular}{|c|c|c|c|c|c|c|c|c|c|c|c|c|c|c|}
\hline \multirow{3}{*}{$\begin{array}{l}\text { Heavy } \\
\text { metals }\end{array}$} & \multicolumn{7}{|c|}{ Summer } & \multicolumn{7}{|c|}{ Post-rainy season } \\
\hline & \multicolumn{5}{|c|}{ Concentration $(\mu \mathrm{g} / \mathrm{l})$} & \multirow{2}{*}{ Mean } & \multirow{2}{*}{ SD } & \multicolumn{5}{|c|}{ Concentration $(\mu \mathrm{g} / \mathrm{l})$} & \multirow{2}{*}{ Mean } & \multirow[t]{2}{*}{ SD } \\
\hline & A1 & A2 & A3 & A4 & A5 & & & $\mathbf{A 1}$ & A2 & A3 & A4 & A5 & & \\
\hline $\mathbf{F e}$ & 200 & 450 & 540 & 680 & 230 & 420 & 204.6 & 252 & 672 & 738.4 & 1059 & 321.1 & 608.5 & 329.2 \\
\hline $\mathbf{P b}$ & 20 & 20 & 40 & 60 & 30 & 34 & 16.7 & 1 & 2.6 & 20 & 30 & 10 & 12.7 & 12.2 \\
\hline Cd & 3 & 4 & 6 & 8 & 4 & 5 & 2 & 0.0 & 0.0 & 0.0 & 4.0 & 0.0 & 0.8 & 1.8 \\
\hline $\mathbf{Z n}$ & 1200 & 1500 & 1800 & 2000 & 1660 & 1632 & 303.5 & 1440 & 1950 & 2700 & 4400 & 1920 & 2482.0 & 634.1 \\
\hline $\mathrm{Cr}$ & 20 & 20 & 50 & 80 & 30 & 40 & 25.5 & 30 & 32 & 85 & 160 & 48 & 71.0 & 54.4 \\
\hline $\mathbf{C u}$ & 150 & 180 & 240 & 570 & 140 & 256 & 179.8 & 100 & 120 & 167 & 430 & 112 & 185.8 & 138.8 \\
\hline $\mathbf{N i}$ & 120 & 150 & 180 & 230 & 150 & 166 & 41.6 & 20 & 87 & 102 & 156 & 68 & 86.6 & 49.6 \\
\hline Mn & 100 & 130 & 180 & 260 & 140 & 162 & 61.8 & 220 & 299 & 450 & 780 & 336 & 417.0 & 219.2 \\
\hline
\end{tabular}

Table.2 Heavy metal Pollution Index (HPI) calculations for river water based on mean heavy metal concentration in summer and post-rainy season

\begin{tabular}{|c|c|c|c|c|c|c|c|c|}
\hline \multirow[b]{2}{*}{$\begin{array}{l}\text { Heavy } \\
\text { Metals }\end{array}$} & \multirow[b]{2}{*}{$\underset{(\mu \mathrm{g} / \mathrm{l})}{\mathbf{S i}}$} & \multirow[b]{2}{*}{$\begin{array}{c}\mathbf{W i} \\
(\mathbf{1} / \mathbf{S i})\end{array}$} & \multicolumn{3}{|c|}{ Summer } & \multicolumn{3}{|c|}{ Post-rainy season } \\
\hline & & & $\begin{array}{c}\text { Mean } \\
\text { concentration } \\
(\mathrm{Mi}, \mu \mathrm{g} / \mathrm{l})\end{array}$ & $\begin{array}{c}\mathbf{Q i} \\
(\mathbf{M i} / \mathbf{S i} \\
* \mathbf{1 0 0})\end{array}$ & $\mathbf{W i} \mathbf{i}^{*} \mathbf{Q}$ & $\begin{array}{c}\text { Mean } \\
\text { concentration } \\
(\mathbf{M i}, \mu \mathrm{g} / \mathbf{l})\end{array}$ & $\begin{array}{c}\mathrm{Qi} \\
(\mathbf{M i} / \mathbf{S i} \\
* \mathbf{1 0 0})\end{array}$ & $\mathbf{W i} \mathbf{H}^{*} \mathbf{Q}$ \\
\hline $\mathbf{F e}$ & 300 & 0.0033 & 420 & 140 & 0.47 & 608.5 & 202.8 & 0.676111 \\
\hline $\mathbf{P b}$ & 10 & 0.1 & 34 & 340 & 34 & 12.7 & 127.2 & 12.72 \\
\hline Cd & 3 & 0.33 & 5 & 166.67 & 55.56 & 0.8 & 26.7 & 8.888889 \\
\hline $\mathbf{Z n}$ & 15000 & 6.66667E-05 & 1632 & 10.88 & 0.00073 & 2482.0 & 16.5 & 0.001103 \\
\hline $\mathrm{Cr}$ & 50 & 0.02 & 40 & 80 & 1.6 & 71.0 & 142.0 & 2.84 \\
\hline $\mathbf{C u}$ & 1500 & 0.0007 & 256 & 17.07 & 0.0114 & 185.8 & 12.4 & 0.008258 \\
\hline $\mathbf{N i}$ & 20 & 0.05 & 166 & 830 & 41.5 & 86.6 & 433.0 & 21.65 \\
\hline Mn & 300 & 0.003 & 162 & 54 & 0.18 & 417.0 & 139.0 & 0.463333 \\
\hline
\end{tabular}

$\Sigma \mathrm{Wi}=0.511, \Sigma \mathrm{Wi} * \mathrm{Qi}($ summer $)=133.31, \mathrm{HPI}($ summer $)=261$

$\Sigma \mathrm{Wi} * \mathrm{Qi}($ summer $)=47.25$, HPI $($ post-rainy season $)=92.5$

Table.3 Heavy metal Pollution Index (HPI) calculations for river water at each sampling site in summer and post-rainy season

\begin{tabular}{|ccc|}
\hline Sampling site & \multicolumn{2}{c|}{ HPI of one site } \\
A1 & Summer & Post-rainy Season \\
A2 & 165.3 & 15.12 \\
A3 & 202.3 & 52.3 \\
A4 & 302.3 & 98.3 \\
A5 & 412.20 & 238.5 \\
Mean HPI & 222.2 & 58.1 \\
\hline
\end{tabular}


Table.4 Metal Quality Index (MQI) calculations for river water at each sampling site in summer and post-rainy season

\begin{tabular}{|c|c|c|}
\hline \multirow{2}{*}{ Sampling Sites } & \multicolumn{2}{|c|}{ MQI } \\
\cline { 2 - 3 } & Summer & Post-rainy season \\
\hline A1 & 9.9 & 3.44 \\
\hline A2 & 11.88 & 8.69 \\
\hline A3 & 16.88 & 13.05 \\
\hline A4 & 23.15 & 22.04 \\
\hline A5 & 13.10 & 7.75 \\
\hline
\end{tabular}

Table.5 Pearson's correlation analysis of heavy metal concentrations at various sampling sites in river water

\begin{tabular}{|c|c|c|c|c|c|c|c|c|}
\hline \multirow{2}{*}{\multicolumn{2}{|c|}{ Heavy metals }} & \multicolumn{7}{|c|}{ Pearson's correlation $(r)$} \\
\hline & & $\mathbf{P b}$ & Cd & $\mathbf{Z n}$ & $\mathrm{Cr}$ & $\mathrm{Cu}$ & $\mathbf{N i}$ & Mn \\
\hline \multirow[b]{2}{*}{$\mathbf{F e}$} & Summer & 0.79 & 0.92 & 0.81 & 0.83 & 0.83 & 0.91 & 0.88 \\
\hline & Post-rainy season & 0.81 & 0.76 & 0.91 & 0.85 & 0.85 & 0.95 & 0.88 \\
\hline \multirow[b]{2}{*}{$\mathbf{P b}$} & Summer & 1 & 0.97 & 0.90 & 0.99 & 0.92 & 0.96 & 0.98 \\
\hline & Post-rainy season & 1 & 0.79 & 0.95 & 0.97 & 0.87 & 0.88 & 0.95 \\
\hline \multirow[b]{2}{*}{ Cd } & Summer & & 1 & 0.92 & 0.98 & 0.92 & 0.99 & 0.99 \\
\hline & Post-rainy season & & 1 & 0.70 & 0.91 & 0.98 & 0.78 & 0.92 \\
\hline \multirow[b]{2}{*}{$\mathbf{Z n}$} & Summer & & & 1 & 0.88 & 0.76 & 0.94 & 0.92 \\
\hline & Post-rainy season & & & 1 & 0.91 & 0.82 & 0.94 & 0.91 \\
\hline \multirow[b]{2}{*}{$\mathrm{Cr}$} & Summer & & & & 1 & 0.94 & 0.96 & 0.98 \\
\hline & Post-rainy season & & & & 1 & 0.97 & 0.88 & 0.99 \\
\hline \multirow[b]{2}{*}{$\mathbf{C u}$} & Summer & & & & & 1 & 0.93 & 0.94 \\
\hline & Post-rainy season & & & & & 1 & 0.86 & 0.97 \\
\hline \multirow[b]{2}{*}{$\mathbf{N i}$} & Summer & & & & & & 1 & 0.99 \\
\hline & Post-rainy season & & & & & & 1 & 0.93 \\
\hline
\end{tabular}

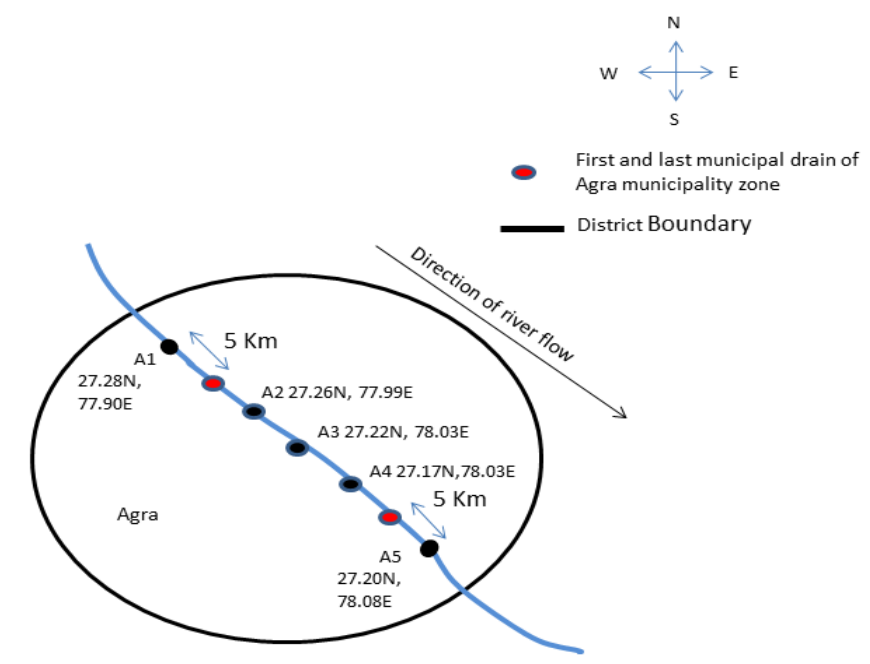

Fig. 1 Systematic representation of five sampling sites along the Yamuna river stretch in Agra 
Intermetallic relations for Yamuna water revealed that there were significant correlations (Pearson correlation tests, $\mathrm{p}<0.05)$ between all the eight metals in both seasons (Table 5).

Positive correlation between metals analysed at different sites showed either an association/interaction between the metals or similar sources of input (Miller and Miller, 2002).

Strong correlation between two heavy metals may be an occurrence of strong dependence of both metals on the same causal factor (Ashraf et al., 2012).

In conclusion, our study on heavy metal pollution of river Yamuna for Agra stretch shows that site A4 is highly polluted mainly due to discharge of Fort drain.

HPI of river shows that Yamuna is critically polluted with heavy metals and unsafe for drinking in both summer and post-rainy seasons. MQI was $>1$ at all sites in both seasons also indicating high metal pollution. Pearson's correlation analysis showed that it can be an effective tool for the identification of the sources of the pollutants. The study has relevance in designing control measures and action plans for reducing pollutants influx into rivers.

The results of the study should be taken earnestly by the concerned water resource management authorities and policy makers for pollution abatement of the river.

\section{Acknowledgement}

The authors are thankful to the Director, Indian Institute of Soil and Water Conservation, Dehradun, Uttarakhand, India, for the approval and giving required facilities to conduct above study.

\section{References}

Abdel-Ghani, N.T., and Elchaghaby, G.A. 2007.Influence of operating conditions on the removal of $\mathrm{Cu}, \mathrm{Zn}, \mathrm{Cd}$ and $\mathrm{Pb}$ ions from wastewater by adsorption. Int $\mathrm{J}$ EnvironSciTechnol, 4:451-456.

Abdel-Satar, A.M., Ali, M.H., and Goher, M.E. 2017.Indices of water quality and metal pollution of Nile River, Egypt.The Egypt J Aqu Res, 43:21-29.

Ahmed,

M.K., Shaheen, N., Islam,M.S., Habibullah-al-Mamun, M., Islam, S., MohiduzzamanMand BhattacharjeeL. 2015.Dietary intake of trace elements from highly consumed cultured fish (Labeorohita, Pangasiuspangasius and $O$ reochromismossambicus) and human health risk implications in Bangladesh.Chemosphere,128:284-92.

Ali, M.M., Ali, M.L., Islam, M.S., and Rahman, M.Z. 2016. Preliminary assessment of heavy metals in water and sediment of Karnaphuli River, Bangladesh. Environ Nanotech MonitManage,5:27-35.

APHA 2012.Standard Methods for examination of water and wastewater, 22nd edn.American Public Health Association, Washington, USA.

Ashraf, M.A., Maah, M.J.,Yussoff, I. 2012. Chemical speciation and potential mobility of heavy metals in the soil of a former tin mining catchment. The Scientific World J, 1:1-11.

Bakan, G., BokeOzkoc, H., Tulek, S., and Cuce, H. 2010. Integrated environmental quality assessment of Kizilirmak River and its coastal environment. Turk J Fish Aquat Sc, 10: 453-462.

BIS 2012. Indian standard drinking water specification IS: 10500. Bureau of Indian Standards, New Delhi.

Jaishankar, M., Tseten, T., Anbalagan, N., Mathew, B.B., and Beeregowda, K.N. 2014. Toxicity, mechanism and health effects of some heavy metals. Interdiscip Toxicol, 7: 60-72. 
Kaur, S. and Mehra, P. 2012. Assessment of heavy metals in summer and winter seasons in River Yamuna segment flowing through Delhi, India. J Environ Ecol, 3:149-165.

Malik, D., Singh, S., Thakur, J., and Singh, R.K.et al., 2014.Review article heavy metal pollution of the Yamuna River: an introspection. Int J Curr Microbiol Appl Sci, 3:856-863.

Manoj, K., Padhy, P.K., and Chaudhury, S. 2012. Study of Heavy Metal Contamination of the River Water through Index Analysis Approach and Environmetrics. Bull Environ Pharmacol Life Sci, 1: $07-15$.

Milivojević, J., Krstić, D., Šmit, B., and Djekić, V. 2016. Assessment of Heavy Metal Contamination and Calculation of Its Pollution Index for Uglješnica River, Serbia. Bull Environ Contam Toxicol, 97:737-742.

Miller, J.N., and Miller, J.C. 2002.Statistics and chemometrics for analytical chemistry, $4^{\text {th }}$ edn, Pearson Education Limited, Harlow, England.

Mohan, S.V., Nithila, P., and Reddy, S.J. 1996.Estimation of heavy metal in drinking water and development of heavy metal pollution index.J Environ Sci Health A, 31:283-289.

Ojekunle, O.Z., Ojekunle, O.V., Adeyemi, A.A., Taiwo, A.G., and Sangowusi, O.R.et al., 2016.Evaluation of surface water quality indices and ecological risk assessment for heavy metals in scrap yard neighbourhood.SprigerPlus,5:560.

Pal, R., and Rai, J, P, N, 2009. Phytochelatins: Peptides Involved in Heavy Metal Detoxification. Appl Biochem Biotechnol, 160:945-963.
Pandey, J., and Singh, R. 2017. Heavy metals in sediments of Ganga River: up- and downstream urban influences. Appl Water Sci, 7:1669-1678.

Paul, B.T., Clement, G.Y., Patlolla, A.K., and Dwayne, JS. 2012. Heavy Metals Toxicity and the Environment' Molecular. Clinical Environ Toxicol, 101:133-164.

Paul, D. 2017. Research on heavy metal pollution of river Ganga: A review. Annals of Agrarian Sc, 15:278-286.

Prasanna, M.V., Praveena, S.M., Chidambaram, S., Nagarajan, R., Elayaraja, A. 2012. Evaluation of water quality pollution indices for heavy metal contamination monitoring: a case study from Curtin Lake, Miri City, East Malaysia. Environ Earth Sci, 67:1987-2001.

Reza, R., and Singh, G. 2010.Heavy metal contamination and its indexing approach for river water. IntJ Environ Sci Technol, 7: 785-792.

Tamasi, G., and Cini, R. 2004. Heavy metals in drinking waters from Mount Amiata. Possible risks from arsenic for public health in the province of Siena. Sci Total Environ, 327: 41-51.

Vukovic, D., Stankovic, S.J., Vukovic, Z., and Jankoviv, K. 2014. Transport and storage of heavy metals in the Sava River Basin in Serbia. J Serbian Chem Soc, 79: 379387.

Yalcin, M.G., Tumuklu, A., Sonmez, M.,and Erdag, D.S. 2010. Application of multivariate statistical approach to identify heavy metal sources in bottom soil of the Seyhan River (Adana), Turkey. Environ Monit Assess, 164:311 -322.

\section{How to cite this article:}

Rama Pal, R.K. Dubey, S.K. Dubey and Singh, A.K. 2017. Assessment of Heavy Metal Pollution through Index Analysis for Yamuna Water in Agra Region. Int.J.Curr.Microbiol.App.Sci. 6(12): 1491-1498. doi: https://doi.org/10.20546/ijcmas.2017.612.166 